\title{
Improving Employee Engagement of Muhammadiyah Teachers with Organizational Trust, Distributive Justice, and Psychological Empowerment
}

\author{
Cut Rifatmi Fadhilaini ${ }^{1 *}$; Heru Kurnianto Tjahjono² ${ }^{2}$ Susanto $^{3}$ \\ 1,2,3 Department of Magister Management, Muhammadiyah University of Yogyakarta \\ Jl. Universitas Muhammadiyah Yogyakarta, Tamantirto, Bantul, Daerah Istimewa Yogyakarta 55184, Indonesia \\ 1'cut.rifatmi.psc16@mail.umy.ac.id; ${ }^{2}$ herukurnianto@umy.ac.id; ${ }^{3}$ susanto@umy.ac.id
}

Received: $23^{\text {rd }}$ February 2021/ Revised: 02 ${ }^{\text {nd }}$ April 2021/ Accepted: $12^{\text {th }}$ April 2021

\begin{abstract}
How to Cite: Fadhilaini, C. R., Tjahjono, H. K., \& Susanto. (2021). Improving employee engagement of Muhammadiyah teachers with organizational trust, distributive justice, and psychological empowerment. The Winners, 22(2), 113-122. https://doi.org/10.21512/tw.v22i2.7085
\end{abstract}

\begin{abstract}
The research aimed to look at the factors that significantly influence the teacher's engagement, especially the factors of organizational trust and distributive justice. In addition, the research was to see the moderating effect of psychological empowerment in the influence of organizational trust on employee involvement and between distributive justice on employee engagement using the hierarchical regression analysis method. The research implemented simple random sampling technique and obtained 150 respondents, who were teachers at Muhammadiyah schools spread across five schools in Kotagede District, Yogyakarta, Indonesia. The results show that organizational trust has a significant effect on employee engagement, while distributive justice does not significantly affect employee engagement. In addition to these factors, psychological empowerment is shown to have a quasi-moderating effect in the effect of organizational trust on employee engagement. Since the analysis is limited to only five Muhammadiyah schools in Kotagede, Yogyakarta, the results cannot generalized. In addition, the COVID-19 pandemic only makes the questionnaires possible via online. Since younger teachers start to dominate, future research is suggested to have a further analysis on different generations ( $\mathrm{X}, \mathrm{Y}$, and $\mathrm{Z}$ ).
\end{abstract}

Keywords: employee engagement, organizational trust, distributive justice, psychological empowerment, school teachers

\section{INTRODUCTION}

The education sector is one of the strategic areas in Muhamadiyah's efforts to increase the benefit of the people. The founder, K. H. Ahmad Dahlan hopes that in the Muhammadiyah organization every cadre sincerely fights for the organization and participates in developing the Muhammadiyah Organization as one of the largest organizations in Indonesia. In other words, employees in institutions under the Muhammadiyah Organization are expected not only to go to work and go home, but also to have engagement with the institutions and the development of the Muhammadiyah Organization.

Muhammadiyah encounters many challenges including: (1) The flow of secularism-materialism is a temptation for Muhammadiyah cadres to be able to uphold their commitment to Muhammadiyah; (2) The impact of global capitalism on development and life orientation towards profit, exploitation and worship of material and worldly pleasures; (3) Must accommodate all levels of society including those from the less fortunate; (4) For younger generation who prefers to become civil servants considered more promising in terms of income, eventually working in a Muhammadiyah charity is the umpteenth choice; (5) Regeneration of cadres is not as fast as the increasing need for human resources makes the organisation, Amal Usaha Muhammadiyah (AUM), has to be open to human resources from outside the organization who are not necessarily familiar with Muhammadiyah's.

In the midst of ongoing challenges, the implementation of organizational values and culture that the founders have sown is not always easy due to the organizations need for highly engaged human resources. Teacher involvement is the main driver of student participation. It is more likely to say that students who engage have 2,5 times chance to get good grades and do well in school. Besides, they are 4,5 times more likely to have future expectations than 
actively disengaged peers are (Gallup, 2016).

In Southeast Asia, Indonesia is in the lowest position in the achievement of Employee Engagement, which is only $8 \%$. Meanwhile $77 \%$ is classified as not engaged and the remaining $15 \%$ is actively disengaged. Furthermore, $49 \%$ of Indonesia's youth are generation Y or familiarly called millennials (born in 1980-1996). This also includes the formation of teachers, which are mostly filled by this generation. Millennials have a tendency of idealistic characters, drivers of change and does not quite have strong bonds. Only $29 \%$ of millennials are engaged with the workplace, whereas $55 \%$ tend to be ambivalent or not engaged compared to the older generation (Gallup, 2016).

It is considered interesting to conduct a research on the employee engagement of teachers in school institutions under the auspices of the Muhammadiyah Branch Leadership Education Council Kotagede (Pimpinan Cabang Muhammadiyah/PCM Kotagede). Given the historical record, PCM Kotagede developed a role in the early days of Muhammadiyah in Yogyakarta. PCM Kotagede is the first branch of Muhammadiyah. In addition, PCM Kotagede is one of the Muhammadiyah branch leaders that are active and advanced, both in the social, health, economic and educational fields.

There are at least two elemantary schools, one junior high school and two senior high school under the auspices of PCM Kotagede. There are at least 233 teachers spread across the five schools under the PCM Kotagede. Along with the increasing years and the growing need for schools for teachers, the existence of senior teachers who were none other than part of the pioneers was slowly being replaced by young workers.

Based on the data, $71 \%$ of the teaching staff are young workers (aged $<40$ years). These young workers come from various heterogeneous backgrounds, not only from cadres or with Muhammadiyah backgrounds, but also from general public. It is the duty of the Muhammadiyah leadership, especially the Dikdasmen (primary and secondary education) council to continue to instill Muhammadiyah values in teachers in the Muhammadiyah autonomous organization environment none other than Muhammadiyah da'wah cadres. This adds to the interest in researching involvement, with the hope that it can contribute to improving the quality of education under PCM Kotagede Primary Education Council in particular.

Employee engagement has a positive relationship with productivity (Moletsane, Tefera, \& Migiro, 2019). Employees who have high involvement with the working organization will carry out their work with all their heart and mind. In fact, sometimes it might exceed the main task assigned to them. In other words, employee involvement is a psychological condition in which employees feel an interest in the company or organization they work for. Consequently, they tend to be motivated in improving their performance to a level beyond job requirements. Employee engagement rates are related to school outcomes, student retention and student achievement (Gallup, 2016).
Employee involvement allows them to have strong loyalty to the company or organization (Niranjan \& Thomas, 2018). Helping the contribution of teachers as Muhammadiyah cadres in the success of the organization, it is necessary to recognize the significant factors in increasing employee involvement both internally and externally. Several weight variables are affected.

Employee trust in the organization has been widely studied to have a positive influence on employee involvement (Hough, Green, \& Plumlee, 2016; Jena, Pradhan, \& Panigrahy, 2017). Building trust in the organization will increase employee willingness to take risks and lead to greater creativity and job involvement. This is in line with what has been described that trust in superiors is shown to be positively correlated with subordinate's work involvement. By increasing employee involvement in the organization, it will indirectly build up their trust in the organization (McManus \& Mosca, 2015). Trust is a condition that determines the success of the empowerment process. An indicator that makes a big contribution in building trust in leader is the employees' view towards their supervisors who can be trusted since they often act for the benefit of employees and never took a chance for himself (Yulianti, 2016). The higher the level of empowerment and trust in employees, the greater the commitment to the organization (Kosar \& Naqvi, 2016).

The success, effectiveness and efficiency of an organization largely depends on the trust between employees in the organization. If the relationship in the work environment is well maintained, performance will be more efficient. However, it is impossible for a job to run successfully if there is distrust of one another (Baştug et al., 2016).

\section{$\mathrm{H}_{1}$ : Organizational trust has a significant positive effect on employee engagement.}

Tjahjono et al. (2019) point that contextual aspects, such as distributive justice, procedural justice, and social capital, play a large role in elaborating satisfaction and organisational commitment. Moreover, organization must improve distributive, procedural, and interactional justice during the process of determining policy and after the implementation of policy due to the positive consequences on pay satisfaction, ethical decision, job satisfaction, affective communication, intention to join and commitment to keep working (Hadi, Tjahjono \& Palupi, 2020).

Distributive justice is the main determinant in predicting employee job satisfaction. Employees who are satisfied with what is obtained from the organization will provide more than what is expected and continue to improve their performance. Conversely, if employees are not satisfied, they tend to see work as tedious and boring. As a result they will work forcibly, even carelessly. Distributive justice and interactional justice positively correlate with four facets of job satisfaction namely, supervision, co-worker, pay, and 
promotion. They did not have correlation with nature of job as a facet of job satisfaction (Dong \& Phuong, 2018). There are correlation between the components of organisational justice and those of job satisfaction varies. Out of the components of organisational justice, only distributive justice has the capability of predicting all components of job satisfaction (Firoozi, Kazemi, \& Sayadi, 2017).

Distributive justice affects perceived organizational support, which has an impact on engagement. Therefore to ensure that employees are optimally engaged with their work, organizations must ensure policies and practices that reinforce employee perceptions of fairness. Tanoto and Sugiharto (2018) show that perceived organizational support becomes the most significant factor for turnover intention, and distributive justice has higher influence on perceived organizational support compared with turnover intention. Hassan et al. (2017) and Tariq, Ilyas, and Abdul (2017) also show that distributive justice has a positive effect on engagement. It is important for the organization to get fairness from the income received by employees to reduce turnover. Pratiwi and Syahrizal (2019) state that justice is distributed positively and significantly on employee engagement. When the company shortens the fair organization in the distribution of results, it will increase employee engagement. A sense of satisfaction will arise in the employee over the distributive welfare provided by the organization, thus employees are encouraged to provide a higher level of involvement. This also seems to apply in the field of education, as evidenced by Septiani and Arwiyah (2018) who conducted research at SMP Muhammadiyah 6 Bandung. They prove that organizational justice has a positive effect on employee engagement. One of the components of distributive justice in the form of compensation is proven to have an effect on employee engagement and performance (Pandita \& Musoli, 2019). Based on the results of previous research, a hypothesis is formulated.

$\mathrm{H}_{2}$ : Distributive justice has a significant positive effect on employee engagement

Based on the ancient work-resource model of work interactions, psychological empowerment can be seen as a resource that enables a person to become involved in work. Psychological empowerment and organizational trust have influence upon affective commitment. Mollamohammadrafie (2019) indicates that the psychological empowerment dimensions, meaning and competence, and the organizational trust dimensions, competency, consistency and loyalty, have significant and positive influence upon affective commitment.

Psychological empowerment is shown to have a significant contribution to employee engagement (Sharma \& Singh, 2018; Abdulrab et al., 2017; Azlan \& Wahab, 2020). Meng and Sun (2019) shows that the relationship between organizational trust and psychological empowerment is mutually influencing, allowing employees to increase self-efficacy and to determine their destiny. Ugwu, Onyishi, and Sánchez (2013) adds that employee trust and psychological empowerment in the organization contribute to forming engagement. Employees who receive good organizational trust and psychological empowerment will show a higher level of interaction than those who do not. The positive relationship between organizational trust and job involvement is stronger for workers who have poor perceptions of psychological empowerment than for those who obtain great empowerment.

Research has shown that psychological empowerment moderates relationships between organizational variables such as social exchange relationships and positive employment outcomes. For example, Kimpah, Ibrahim, and Raudeliuniene (2017) find that psychological empowerment moderates the relationship between developmental experience and perceived organizational support. Kirrane, Kilroy and O'Connor (2019) point out that team psychological empowerment moderates the negative relationship between abusive supervision and engagement (vigour and dedication components). Thus this research argues that psychological empowerment moderates the relationship between organizational trust and employee interactions in such a way that the relationship between trust and interaction is more pronounced when empowerment is poor. Therefore hypothesis are formulated:

$\mathrm{H}_{3}$ : Psychological empowerment moderates the relationship between organizational trust and employee engagement

$\mathrm{H}_{4}$ : Psychological empowerment moderates the relationship between distributive justice and employee engagement

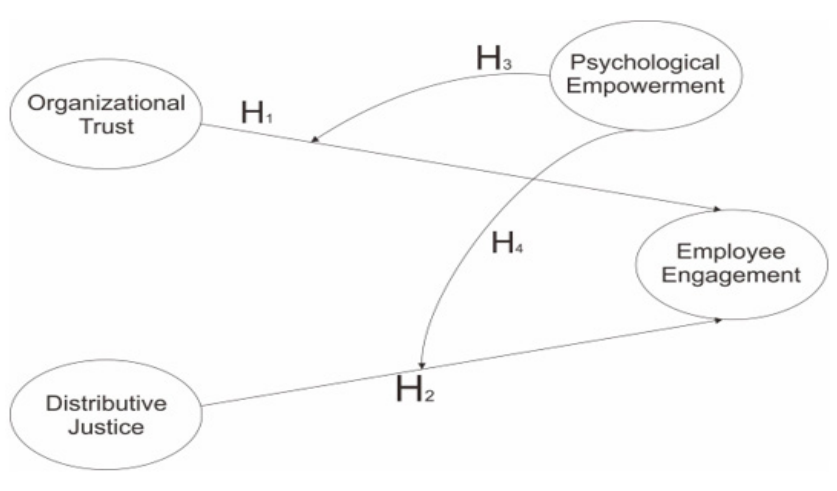

Figure 1 Conceptual Model

\section{METHODS}

The research applies a simple random sampling technique, in which each element of the population has an equal chance of being selected as a sample or research subject (Turner, 2019). The respondents are teachers at five Muhammadiyah schools spread across Kotagede District, Yogyakarta, Indonesia. 
Measurements are made using a five-point Likert scale $(1=$ strongly disagree; 2 = disagree; $3=$ neutral; $4=$ agree; and $5=$ strongly agree). The scale used for the employee engagement variable uses a scale validated by Schaufeli et al. (2002) which consists of 12 statement items. Organizational trust variables are measured using a scale made by Shockley-Zalabak, Ellis, and Cesaria (1999) in accordance with the Organizational Trust Index (OTI) of 29 statement items. Meanwhile, the distributive justice variable is measured using a scale which consists of 4 question items related to outcomes (Leventhal, 1976 in Tjahjono, 2007). The psychological empowerment variable uses a scale which includes the four dimensions, namely meaning, competence, self-determination and impact (Spreitzer, 2007). Based on the Slovin formula, the minimum sample that can represent 233 members of the population is 147 samples, but the research obtains 150 respondents. The data analysis technique uses the Hierarchical Regression Analysis through the SPSS 25.0. This method is to see the influence between the independent and dependent variables and to see the interaction effect or moderation effect.

Table 1 Demographic Data of Respondent

\begin{tabular}{lcc}
\hline \multicolumn{1}{c}{ Category } & Frequency & \% \\
\hline Gender & & \\
Male & 62 & $41,3 \%$ \\
Female & 88 & $58,7 \%$ \\
Age & & \\
Less than 25 years & 14 & $9,3 \%$ \\
25 to 40 years & 92 & $61,3 \%$ \\
More than 40 years & 44 & $29,3 \%$ \\
Experience & & \\
Less than 1 year & 5 & $3,3 \%$ \\
1 to 2 years & 29 & $19,3 \%$ \\
2 to 3 years & 11 & $7,3 \%$ \\
More than 3 years & 105 & $70,0 \%$ \\
\hline
\end{tabular}

Table 1 shows that the majority of respondents are female $(58,7 \%)$. Considering the age, the majority of respondents are 25 to 40 years $(61,3 \%)$. In terms of experience, most of the employees have worked for more than 3 years $(29,3 \%)$. The data show that they are a very experienced workforce.

\section{RESULTS AND DISCUSSIONS}

To test the feasibility of each statement item or question posed in the research questionnaire, it is necessary to test the validity, as presented in Table 2 . This test is done by comparing the calculated $\mathrm{r}$ value with $\mathrm{r}$ table with $\mathrm{df}=\mathrm{n}-2$ and a significance level of $5 \%$. This test is carried out on each item of the statement. If the value of $r$ table $<r$ count then it is declared valid. In other words the question or statement posed is feasible in defining a predetermined variable. The research has 150 respondents, so the value of $\mathrm{df}=150-2=148$ and $\alpha=0,5$, hence the value of $r$ table is 0,1348 .

Moreover, a reliability test is conducted. All variables have to construct reliability values of more than 0,7 (Ghozali, 2018), which means that the constructs are reliable, as seen in Table 3 . Before the data is analyzed using hierarchical regression analysis method, it must be ensured that the data meet the classical assumptions. The normality test for data above 50 uses the Kolmogorov-Smirnov test. Based on the research data, the Sig. is 0,082 (Table 4). This value is greater than the value of $\alpha=0,05$, so the decision is to reject $\mathrm{H}_{0}$. This means that the data is normally distributed. In other words, the data fulfills the assumption of normality.

The heteroscedasticity test serves to test whether the regression model has an inequality of variance from the residuals of one observation to another. If the variance is the same or constant, it is called homoscedasticity. This can be seen from the residual scaterplot formed from the observation data points, as shown in Figure 2. If the dots spread out and do not form a certain pattern, it can be stated that the data meets the homoscedasticity assumption. The data are spread, so it fulfills the assumption of homoscedasticity.

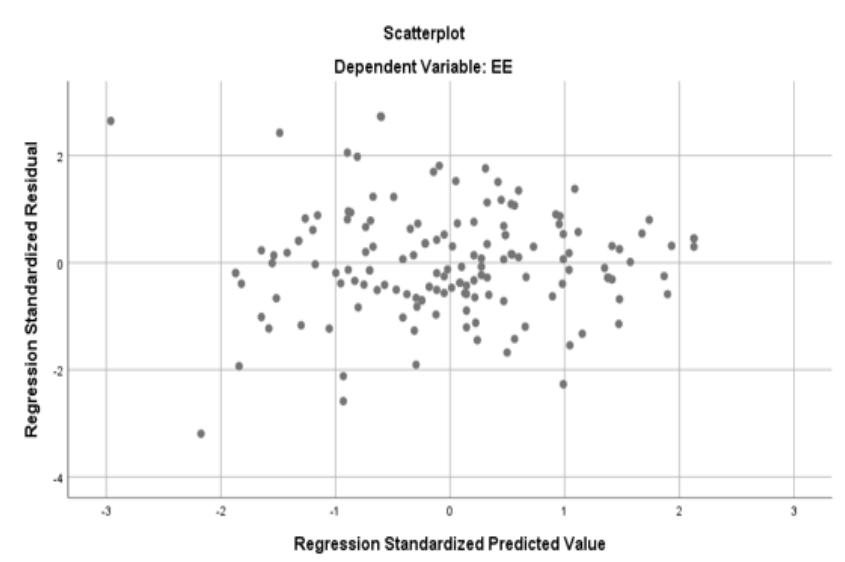

Figure 2 Scaterplot of Residuals Data

A good regression model should not have correlation between independent variables. If there is a correlation, the result shows that it is not orthogonal or there is a similarity. Orthogonal variables are independent variables whose correlation value between independent variables is 0 . Multicollinearity test is used to detect any correlation between variables (Table 5). The independent variable is said not to occur multicollinearity if the tolerancy value is $>0,1$ and the Variance Inflation Factor (VIF) $<10$.

The research has two independent variables, namely organizational trust and distributive justice. The tolerance value for the two variables is 0,642 . This value is more than 0,1 . Likewise, the VIF value that is more than 1,557 is less than 10 . It can be concluded that there is no multicollinearity in the two independent variables. 
Table 2 Validity Test of Instruments

\begin{tabular}{|c|c|c|c|c|c|c|c|c|}
\hline Indicator & $\mathbf{r}_{\text {count }}$ & Decision & Indicator & $\mathbf{r}_{\text {count }}$ & Decision & Indicator & $\mathbf{r}_{\text {count }}$ & Decision \\
\hline \multicolumn{3}{|c|}{ Employee Engagement } & \multicolumn{3}{|c|}{ Organizational Trust } & \multicolumn{3}{|c|}{ Organizational Trust } \\
\hline EE1 & 0,602 & Valid & OT1 & 0,680 & Valid & OT23 & 0,748 & Valid \\
\hline EE2 & 0,681 & Valid & OT2 & 0,611 & Valid & OT24 & 0,755 & Valid \\
\hline EE3 & 0,538 & Valid & OT3 & 0,674 & Valid & OT25 & 0,570 & Valid \\
\hline EE4 & 0,559 & Valid & OT4 & 0,622 & Valid & OT26 & 0,619 & Valid \\
\hline EE5 & 0,691 & Valid & OT5 & 0,481 & Valid & OT27 & 0,693 & Valid \\
\hline EE6 & 0,661 & Valid & OT6 & 0,484 & Valid & OT28 & 0,618 & Valid \\
\hline EE7 & 0,649 & Valid & OT7 & 0,497 & Valid & OT29 & 0,662 & Valid \\
\hline EE8 & 0,640 & Valid & OT8 & 0,669 & Valid & & & \\
\hline EE9 & 0,698 & Valid & OT9 & 0,662 & Valid & & & \\
\hline EE10 & 0,658 & Valid & OT10 & 0,677 & Valid & \multicolumn{3}{|c|}{ Psychological Empowerment } \\
\hline EE11 & 0,674 & Valid & OT11 & 0,702 & Valid & $\overline{\text { PE1 }}$ & 0,593 & Valid \\
\hline EE12 & 0,198 & Valid & OT12 & 0,711 & Valid & PE2 & 0,706 & Valid \\
\hline EE13 & 0,548 & Valid & OT13 & 0,686 & Valid & PE3 & 0,651 & Valid \\
\hline EE14 & 0,633 & Valid & OT14 & 0,689 & Valid & PE4 & 0,674 & Valid \\
\hline EE15 & 0,613 & Valid & OT15 & 0,666 & Valid & PE5 & 0,709 & Valid \\
\hline EE16 & 0,645 & Valid & OT16 & 0,756 & Valid & PE6 & 0,625 & Valid \\
\hline EE17 & 0,706 & Valid & OT17 & 0,647 & Valid & PE7 & 0,648 & Valid \\
\hline \multicolumn{3}{|c|}{ Distributive Justice } & OT18 & 0,719 & Valid & PE8 & 0,634 & Valid \\
\hline DJ1 & 0,784 & Valid & OT19 & 0,744 & Valid & PE9 & 0,608 & Valid \\
\hline DJ2 & 0,860 & Valid & OT20 & 0,672 & Valid & PE10 & 0,550 & Valid \\
\hline DJ3 & 0,861 & Valid & OT21 & 0,706 & Valid & PE11 & 0,551 & Valid \\
\hline DJ4 & 0,829 & Valid & OT22 & 0,700 & Valid & PE12 & 0,614 & Valid \\
\hline
\end{tabular}

Table 3 Reliability Test

\begin{tabular}{lcc}
\hline \multicolumn{1}{c}{ Variable } & Cronbach's Alpha & Conclusion \\
\hline Employee Engagement $(\mathrm{Y})$ & 0,915 & Reliable \\
Organizational Trust $\left(\mathrm{X}_{1}\right)$ & 0,959 & Reliable \\
Distributive Justice $\left(\mathrm{X}_{2}\right)$ & 0,928 & Reliable \\
Psychological Empowerment $(\mathrm{M})$ & 0,901 & Reliable \\
\hline
\end{tabular}

Table 4 The Normality Test

\begin{tabular}{lccc}
\hline \multicolumn{4}{c}{ Kolmogorov-Smirnov } \\
\hline & Statistic & df & Sig. \\
\hline Unstandardized Residual & 0,068 & 150 & 0,082 \\
\hline
\end{tabular}

Table 5 Multicollinearity Test

\begin{tabular}{|c|c|c|c|c|c|c|c|c|}
\hline \multirow{2}{*}{ Model } & \multicolumn{2}{|c|}{$\begin{array}{l}\text { Unstandardized } \\
\text { Coefficients }\end{array}$} & \multirow{2}{*}{$\begin{array}{c}\begin{array}{c}\text { Standardized } \\
\text { Coefficients }\end{array} \\
\text { Beta }\end{array}$} & \multirow{2}{*}{$\mathbf{t}$} & \multirow{2}{*}{ Sig. } & \multicolumn{2}{|c|}{ Collinearity Statistics } & \multirow{2}{*}{ Decision } \\
\hline & B & Std. Error & & & & Tolerance & VIF & \\
\hline (Constant) & 24,092 & 3,831 & & 6,288 & 0,000 & & & \\
\hline OT & 0,371 & 0,042 & 0,676 & 8,820 & 0,000 & 0,642 & 1,557 & No multicollinearity \\
\hline DJ & $-0,042$ & 0,220 & $-0,015$ & $-0,192$ & 0,848 & 0,642 & 1,557 & No multicollinearity \\
\hline
\end{tabular}


This descriptive analysis is used to see the characteristics description of the respondents' response to each statement item from the questionnaire. The analysis uses the average value and a percentage of the score of respondents' answers, which are grouped based on interval calculations. The research uses a Likert scale consisting of five scales. The respondents data on each statement item will be grouped into five categories with a scale range of 0,8 , namely very low, low, medium, high, and very high. Based on the results of the respondent's answers, the average value of all indicators for each variable is calculated, and the high categories are obtained for the four variables. The average value of the four variables is in the range of $3,41-4,20$, so all falls into the high category (see Table 6).

The statistical analysis technique is hierarchical regression analysis with the SPSS 25 application. In step one, based on the simultaneous test results, the ANOVA calculation results are obtained, where $\mathrm{F}$ count is 59,025 and Sig 0,000 . That way the model is simultaneously significant. However, in partial testing, the variable distributive justice obtained a Sig value of 0,848 , which is greater than the predetermined significance level of 0,05 . It can be concluded that the variable distributive justice does not significantly affect employee engagement. Furthermore, regression analysis is carried out without including the variable distributive justice and the $\hat{Y}_{1,2}$ model is proven to be significant. This means that there is a positive influence from the organizational trust variable on employee engagement with a coefficient of 0,667 . This shows that higher organizational trust will certainly also increase employee engagement of teachers in Muhammadiyah schools within the PCM Kotagede scope.

The second step is the test that involves two equation models. The model contains independent variables organizational trust and distributive justice by adding moderating variable (psychological empowerment) into the equation. The test results show that both equations are significant since the Sig value for the moderating variable in both equations is 0,000 , less than $\alpha=5 \%$. The resulting R-squared also has an increase when compared to the test in the previous stage.

The third step is to test whether there is a moderating effect of the psychological empowerment variable on the effect of the independent variable (organizational trust) on the dependent variable (employee engagement) as well as distributive justice towards employee engagement. An analysis is carried out by adding the interactions between each independent variable and the moderating variable $\left(\mathrm{X}_{1}^{*} \mathrm{M}\right.$ and $\left.\mathrm{X}_{2}^{*} \mathrm{M}\right)$ as the independent variables.

Based on the results of regression analysis shown in Table 7, it can be denied to answer $\mathrm{H}_{1}$ that organizational trust has a significant positive effect on employee engagement. This shows that more organizational trust of teachers in school organizations will increase the employee engagement of teachers. The decreasing organizational trust of teacher can reduce the involvement of teaching staff employees.

Organizational trust consists of five dimensions, namely: 1) competence, 2) openness and honesty, 3) concern for employees, 4) reliability, and 5) identification. The results show that the dimensions of

Table 6 Mean Score Based on Variables and Age Generation

\begin{tabular}{lcccccccc}
\hline \multirow{2}{*}{ Variable } & \multirow{2}{*}{ Mean } & \multirow{2}{*}{ Category } & \multicolumn{6}{c}{ Mean by generation } \\
\cline { 5 - 10 } & & & Gen Z (>25) & Gen Y (25-40) & Gen X (>40) \\
\hline Employee Engagement $(\mathrm{Y})$ & 3,98 & High & 3,82 & High & 3,97 & High & 4,06 & High \\
Organizational Trust $\left(\mathrm{X}_{1}\right)$ & 3,85 & High & 3,64 & High & 3,82 & High & 3,99 & High \\
Distributive Justice $\left(\mathrm{X}_{2}\right)$ & 3,72 & High & 3,21 & Medium & 3,68 & High & 3,99 & High \\
Psychological Empowerment $(\mathrm{M})$ & 3,99 & High & 3,81 & High & 4,00 & High & 4,00 & High \\
\hline
\end{tabular}

Table 7 Hierarchical Regression Results and Test of Moderation

\begin{tabular}{|c|c|c|c|c|c|c|c|c|c|}
\hline \multirow{2}{*}{ Step } & \multirow{2}{*}{ Model Equation } & \multirow{2}{*}{$\mathbf{R}^{2}$} & \multirow{2}{*}{$\begin{array}{c}\mathbf{R}^{2} \\
\text { change }\end{array}$} & \multicolumn{2}{|c|}{ ANOVA } & \multicolumn{4}{|c|}{ Sig. } \\
\hline & & & & $\mathbf{F}$ & Sig. & $X_{1}$ & $X_{2}$ & $\mathbf{M}$ & $X_{i}^{*} \mathbf{M}$ \\
\hline \multirow[t]{2}{*}{1} & $\hat{Y}_{1,1}=0,676 X_{1}-0,015 X_{2}$ & 0,445 & 0,000 & 59,025 & 0,000 & 0,000 & 0,848 & - & \\
\hline & $\hat{Y}_{1,2}=0,667 X_{1}$ & 0,445 & 0,000 & 118,786 & 0,000 & 0,000 & - & - & \\
\hline \multirow[t]{2}{*}{2} & $\hat{Y}_{2,1}=0,386 X_{1}+0,480 M$ & 0,597 & 0,152 & 108,727 & 0,000 & 0,000 & - & 0,000 & \\
\hline & $\hat{Y}_{2,2}=0,412 X_{2}+0,652 M$ & 0,516 & 0,071 & 78,506 & 0,000 & - & 0,023 & 0,000 & \\
\hline \multirow[t]{2}{*}{3} & $\hat{Y}_{3,2}=1,491 X_{2}+1,447 M+1,854 X_{2} M$ & 0,625 & 0,028 & 80,964 & 0,000 & 0,000 & & 0,000 & 0,001 \\
\hline & $\hat{Y}_{3,3}=0,543 X_{2}+0,910 M-0,554 X_{2} M$ & 0,519 & 0,003 & 52,582 & 0,000 & - & 0,212 & 0,002 & 0,352 \\
\hline
\end{tabular}

Note:

$X_{1}$ : Organizational Trust

$X_{2}$ : Distributive Justice

M: Psychological Empowerment 
competence and openness and honesty are proven to be significant in influencing employee engagement. The competency dimension is related to the confidence of teachers in seeing how effective their colleagues and leaders are, as well as the organization as a whole. This dimension is also a measure of how strong teachers believe in the organization's ability to compete and survive in the market. In addition, the dimension of openness and honesty is proven to significantly affect employee engagement. Organizations that are able to provide accurate information and provide sufficient information so as not to raise suspicion can certainly achieve the trust of teachers in the organization. One of the products is the high loyalty associated with teachers to the organization.

For $\mathrm{H}_{2}$, the result shows that distributive justice does not significantly affect employee engagement. This is in line with Tjahjono \& Palupi (2017) pointing out distributive justice has no effect on affective commitment, while procedural justice has a positive effect on affective commitment. Data analysis shows that the loyalty of teachers as a product of engagement is not solely influenced by the material received. There are other factors that are more dominant in influencing on how strong the perceived engagement is, so that it can increase involvement and loyalty in working and joining Muhammadiyah. That way the concept that is taught and always implanted in all Muhammadiyah cadres, especially in the school of Muhammadiyah PCM Kotagede scope, can be said to be successful.

In $\mathrm{H}_{3}$, psychological empowerment variables are sufficient evidence as a quasi moderator in the influence of organizational trust variables on employee engagement. Quasi moderator or pseudo moderation is a variable that moderates the relationship between the independent variable (organizational trust) and the dependent variable (employee engagement) as well as being the independent variable. This means that in addition to influencing employee engagement, psychological empowerment can also strengthen the influence of organizational trust on employee engagement.

According to Spreitzer (2007), there are four dimensions of psychological empowerment, namely meaning, competence, self-determination, and impact. The research shows that three of the dimensions are proven to significantly influence employee engagement, where the amount of contribution is based on the dimensions of competence, meaning, and impact.

Competence refers to self-efficacy that is specific to a job. Teacher's confidence in their skills and abilities can motivate them to do a good performance. Meanwhile, dimension of meaning refers to the conformity between a person's job role needs and a person's beliefs, values and behavior. The impact dimension is a description of the extent to which teaching staff can influence strategy, administration, or work results. In this dimension, there is more to the contribution of the involvement of teachers to the organization.
Lastly, for $\mathrm{H}_{4}$, there is no moderating effect of psychological empowerment on the effect of distributive justice on employee engagement. Simultaneous distributive justice together with the organizational trust variable is not proven to have an effect on employee engagement, so the possibility of a moderating effect is not proven.

Organizational trust between superiors and subordinates, as well as between colleagues, is essential. Everything that the leader does is able to represent the organization, so it is important for a leader to have integrity in what is said and done. In addition, good leaders are able to communicate openly, participate in carrying out control functions wisely, solve misunderstandings with tabayyun (clarify), and provide correct information. Therefore, the teaching staffs' trust will be well-established, and it certainly will also increase teachers' engagement with the organization.

Schools that are under the auspices of the Muhammadiyah Kotagede Branch Leadership Dikdasmen have a pure source of funds from student payment income. There is no financial support from the Muhammadiyah foundation, so that Muhammadiyah schools must be smart in allocating their income for all forms of expenditure. One of them is in the allocation of salaries for teaching staff and also for their education personnel.

So far, the average salary of teaching staff and also education personnel is below the city minimum wage limit. However, based on research data, the variable of distributive justice is descriptively high. This shows that although their salary does not reach the city minimum wage limit, they are able to achieve justice.

Data analysis shows that the loyalty of teachers as a product of their involvement is not merely a source of the material received. There are other factors that are more dominant in influencing the perceived influence so that it can increase interaction and loyalty in working and joining Muhammadiyah.

That way the concept of sincerity in Muhammadiyah which is taught and instilled in all Muhammadiyah cadres, especially in Kotagede's school can be said to be successful. However, even though distributive justice proved insignificant in influencing the Involvement of Teachers, it does not mean that Muhammadiyah Branch and/or School Leaders neglect fairness of distribution, especially in the distribution of payroll. The variables provided are very sensitive in the world of work.

Observed in the descriptive analysis, the mean score at $\mathrm{Z}$ generation indicates different categories. In $\mathrm{Z}$ generation, it is included in the medium category, while the generation above it is in the high category, even though the existence of $\mathrm{Z}$ generation will continue to grow and shift previous generations. This allows for a shift in the perception of the distributive justice of teachers.

The increasing demands of life and the soaring dreams can have an impact on the shaky loyalty 
of the teaching staff, creating a young perception that distributive justice is not optimally achieved, especially when the teaching staff comes from a general background, not from Muhammadiyah. Besides, young age is also one of the reasons for being able to try several ways in other workplaces that offer a more attractive employment system. This is a challenge for Muhammadiyah schools to get quality teachers. Given the role of teachers is very important in creating a nation. It is not uncommon for Muhammadiyah schools to lose teachers who prefer to become civil servants or work in other schools that can provide more salaries.

In addition, teachers who have fulfilled their daily needs tend to be of a higher quality at work. Teachers do not need to bother looking for additional income by doing a side business to make ends meet. By doing a side business, it certainly will take your time, energy, and thoughts. This has an impact on minimal learning time. They do not have more time to read books and tend to self-develop, and explores effective and creative learning methods in educating students. In other words, if the teachers are prosperous, they ideally can focus more on learning in school.

On the other hand, exhaustion is also a factor in the emergence of unstable emotions. In fact, teachers are required to be able to provide excellent service in educating students. Teachers feel more tired and bored, since they try to give maximum performance only to get minimal appreciation. This certainly has an impact on the products of education in Muhammadiyah schools. For this reason, in an effort to achieve positive performance, schools must create a work environment that can be trusted and be capable of achieving psychological empowerment and justice.

\section{CONCLUSIONS}

The research aims to analyze the effect of organizational trust, distributive justice, and psychologicalempowerment on employee engagement. Based on the results of data analysis through SPSS 25.0 and hierarchical regression analysis, there are four conclusions. First, organizational trust has a positive and significant effect on employee engagement. Second, there is not significant effect of distributive justice on employee engagement. Third, psychological empowerment is significant as a quasi moderator in the influence of organizational trust variables on employee engagement. Lastly, psychological empowerment does not have a moderating effect on the effect of distributive justice on employee engagement.

The research findings show that organizational trust, distributive justice, and psychological empowerment have an essential role in improving employee engagement. The results can be valuable information for schools management and Majelis Dikdasmen Muhammadiyah in making policies that can encourage employee engagement improvement. First, it can be a concern in achieving loyalty and involvement of teachers in organizations. Given the importance and magnitude of influence on student success as the main product of the school, employee engagement needs to be one of the goals that must be achieved by schools. Second, Schools can prioritize achieving the confidence of their teachers in the organization. Third, even though distributive justice is not proven to significantly affect the employee engagement of teachers, it does not mean that the Muhammadiyah organization and school leaders of Muhammadiyah ignore distributive justice, especially in remuneration. Given this variable is very sensitive in the world of work. Last, psychological empowerment contributes to the achievement of employee engagement. As a leader, he can create a work environment that can foster motivation and attachment to work so that it can generate engagement.

The research has limitations that need to be considered for further research. First, the research object is only limited to five schools in Kotagede District of Yogyakarta, Indonesia, so these results cannot be generalized. Second, sampling is carried out during the pandemic, so it is only possible with an online questionnaire without direct meetings. This allows for misunderstandings in comprehending the contents of the statements in the questionnaire. Third, seeing the phenomenon of the shift in senior and younger teachers who are increasingly dominating, it is necessary to conduct a more in-depth analysis to see if there are differences between generations ( $\mathrm{X}, \mathrm{Y}$ and $\mathrm{Z}$ ).

\section{REFERENCES}

Abdulrab, M., Zumrah, A. R., Almaamari, Q., \& Altahitah, A. (2017). The role of psychological empowerment on work engagement: The development of conceptual framework. International Journal of Business Management and Economic Research, 8(6), 1157-1163.

Azlan, S. N. \& Wahab, A. R. A. (2020). Does psychological empowerment contribute to employee's engagement in companies? International Journal of Humanities and Social Science Invention, 9(5), 6-14.

Baştug, G., Pala, A., Kumartasli, M., Gunel, I., \& Duyan, M. (2016). Investigation the relationship between organizational trust and organizational commitment. Universal Journal of Educational Research, 4(6), 1418-1425. https://doi.org/10.13189/ ujer.2016.040619

Dong, L. N. T. \& Phuong, N. N. D. (2018). Organizational justice, job satisfaction and organizational citizenship behavior in higher education institutions: A research proposition in Vietnam. Journal of Asian Finance, Economics and Business, 5(3), 113-119. http://dx.doi.org/10.13106/jafeb.2018.vol5.no3.113

Firoozi, M., Kazemi, A., \& Sayadi, N. (2017). A study of the relationship between the components of organizational justice and the dimensions of job satisfaction of physical education teachers. Pertanika Journal Social Sciences and Humanities, 25(2), 541- 
552.

Gallup. (2016). The Howard county public school system: employee and student survey results. Washington D.C.: Gallup, Inc.

Ghozali, I. (2018). Application of Multivariate Analysis with the IBM SPSS 25 update PLS regression program. Semarang: Diponegoro University Publishing Agency.

Hadi, S., Tjahjono, H. K., \& Palupi, M. (2020). Study of organizational justice in SMEs and positive consequence: Systematic review. International Journal of Advance Science and Technology, 29(3), 4717-4730. http://sersc.org/journals/index.php/ IJAST/article/view/5686

Hassan, Z., Khattak, M. A., Saleem, Z., \& Rajput, A. A. (2017). The mediating role of employee engagement between the relationship of distributive justice and organizational citizenship behavior: Empirical evidence from aviation sector of Pakistan. International Journal of Management Sciences, Research Academy of Social Science, 2(1), 494-500.

Hough, C., Green, K., \& Plumlee, G. (2016). Environmental impact of ethics and organizational beliefs on employee engagement. Journal of Legal, Ethical and Regulatory Issues, 18(3), 45-67

Jena, L. K. Pradhan, S., \& Panigrahy, N. P. (2017). Pursuit of organisational trust: Role of employee engagement, psychological well-being and transformational leadership. Asia Pasific Management Review, 22(3), 1-17. http://dx.doi.org/10.1016/j.apmrv.2017.11.001

Kimpah, J., Ibrahim, H. I., \& Raudeliuniene, J. (2017). The role of psychological empowerment as the moderator between developmental experience and perceived organizational support. Advanced Science Letters, 23(1), 333-336. http://dx.doi.org/10.1166/ asl.2017.7175

Kirrane, M., Kilroy, S., \& O'Connor, C. (2019). The moderating effect of team psychological empowerment on the relationship between abusive supervision and engagement. Leadership \& Organization Development Journal, 40(1), 31-44. https://doi.org/10.1108/LODJ-07-2018-0252

Kosar, R. \& Naqvi, S. M. M. R. (2016). Psychological empowerment and employee behavior employee involvement as mediator and leader exchange as mediator. Journal of International Business Research and Marketing, 1(6), 24-30. https://doi. org/10.18775/jibrm.1849-8558.2015.16.3004

McManus, J. \& Mosca, J. (2015). Strategies to build trust and increase employee engagement. International Journal of Management \& Information Systems, 19(1), 37-42. https://doi.org/10.19030/ijmis. v19i1.9056

Meng, Q. \& Sun, F. (2019). The impact of psychological empowerment on work engagement among university faculty members in China. Psychology Research and Behavior Management, 12, 983-990. http://dx.doi.org/10.2147/PRBM.S215912

Moletsane, M., Tefera, O., \& Migiro, S. (2019). The relationship between employee engagement and organisational productivity of sugar industry in
South Africa: The employees' perspective. African Journal of Business and Economic Research, 14, 113-134. http://dx.doi.org/10.31920/17504562/2019/V14n1a6

Mollamohammadrafie, H. (2019). The effect of psychological empowerment and organizational trust on affective commitment evidence from Padjadjaran University, Bandung Indonesia. International Journal of Scientific \& Technology Research, 8(1), 63-69.

Niranjan, S. \& Thomas, M. (2018). The impact of employee engagement on employee loyalty. International Journal of Trend in Scientific Research and Development, 2(3), 324-331. https://doi. org/10.31142/ijtsrd10914

Pandita, A. D. R \& Musoli. (2019). The effect of compensation distributive justice and compensation procedural justice on employee engagement and performance of PT. Ameya Livingstyle Indonesia. Journal of Business Theory and Implementation, 10(1), 16-30. https://doi.org/10.18196/bti.101112

Pratiwi, M. R. \& Syahrizal. (2019). The effect of distribution justice and procedural justice on employee engagement with perceptions of organizational support as a mediation variable at PT Bangun Persada Kahuripan. Journal of Management and Entrepreneurial Studies, 1(2), 34-43. http://dx.doi. org/10.24036/jkmw0263950

Schaufeli, W. B., Salanova, M., González-romá, V., \& Bakker, A. (2002). The measurement of engagement and burnout: A two sample confirmatory factor analytic approach. Journal of Happiness Studies, 3(1), 71-92. https://doi.org/10.1023/A:1015630930326

Septiani, F. \& Arwiyah, Y. (2018). The effect of organizational justice on employee engagement (A study at SMP Muhammadiyah 6 Bandung). e-Proceeding of Management, 5(3), 3951-3957.

Sharma, N. \& Singh, V. K. (2018). Psychological empowerment and employee engagement: Examining the mediating effects of constructive deviations in the Indian IT sector. International Journal of Human Resources and Information Technology Professionals, 9(4), 44-55. https://doi. org/10.4018/IJHCITP.2018100103

Shockley-Zalabak, P., Ellis, K., \& Cesaria, R. (1999). Measuring Organizational Trust: Trust and Distrust across Cultures. University of Colorado at Colorado Springs. Colorado: Colorado Springs.

Spreitzer, G. M. (2007). Taking stock: A review of more than twenty years of workplace empowerment research. In C. Cooper and J. Barling (Eds.), The SAGE Handbook of Organizational Behavior. Sage Publications. http://dx.doi.org/10.4135/9781849200448.n4

Tanoto, S. R. \& Sugiharto, M. Y. (2018). The impact of distributive justice and perceived organizational support on turnover intention within the poultry industry. International Journal of Business Studies. 1(2), 88-97. https://doi.org/10.9744/ijbs.1.2.88-97

Tariq, H., Ilyas, M., \& Abdul R, C. (2017). Assessing employee loyalty through organizational attributes in telecom sector: An empirical evidence. Advances 
in Social Sciences Research Journal, 4(8), 119-129. https://doi.org/10.14738/assrj.48.3096

Tjahjono, H. K. (2007). Validasi item-item keadilan distributif dan keadilan prosedural: Aplikasi Structural Equation Modeling (SEM) dengan Confirmatory Factor Analysis (CFA). Jurnal Akuntani dan Manajemen, 18(2), 115-125. http:// repository.umy.ac.id/handle/123456789/2649

Tjahjono, H. K., Fachrunnisa, O., \& Palupi, M. (2019). Configuration of organizational justice and social capital: Their impact on satisfaction and commitment. Inderscience Enterprises Journal Business Excellence, 17(3), 336-360. http://dx.doi. org/10.1504/IJBEX.2019.097957

Tjahjono, H. K. \& Palupi, M. (2017). A model of 3 concept of justice and its impact toward affective commitment of disable employees in Indonesia. International Journal of Business Quantitative Economics and Applied Management Research, 4(7), 1-7.

Turner, D. P. (2019). Sampling methods in research design. Headache, 60(1), 8-12. https://doi.org/10.1111/ head. 13707

Ugwu, F. O., Onyishi, I. E., \& Sánchez, A. M. R. (2013). Linking organizational trust to employee engagement: The role of psychological empowerment. Personnel Reviews, 43(3), 377-400. http://dx.doi.org/10.1108/ PR-11-2012-0198

Yulianti, P. (2016). Procedural justice, organizational trust, organizational identification dan pengaruhnya pada employee engagement. Journal of Theory and Applied Management, 9(3), 210-225. http://dx.doi. org/10.20473/jmtt.v9i3.3076 